\title{
Adult polycystic kidney disease in a kindred of West Indian origin exhibits linkage with the $3^{\prime} \mathrm{HVR}$ probe on chromosome 16
}

\author{
Stephen Jeffery, A J Wing, M Patton
}

\begin{abstract}
In a large pedigree of Caribbean origin with adult polycystic kidney disease, linkage has been established to the $3^{\prime} \mathrm{HVR}$ probe on chromosome 16 . Although there are five different fathers in this pedigree, only one of whom was available for DNA analysis, the polymorphic nature of $3^{\prime}$ HVR has enabled gene tracking to be carried out. The same allele cosegregates with the disease in every affected family member.
\end{abstract}

Adult polycystic kidney disease (APKD) is the second most common autosomal dominant disorder in Britain. It has been established since 1985 as being linked to the $\alpha$ globin gene cluster on chromosome $16 .{ }^{1}$ Several studies since then have suggested that in spite of the varying age of onset and severity of the disease most families show linkage to chromosome $16 .^{23}$ Recent reports have shown that in three families with clinical features indistinguishable from chromosome 16 linked APKD, there is no linkage to the $\alpha$ globin $3^{\prime}$ HVR probe. ${ }^{4-6}$ One of the families was Italian ${ }^{4}$ and the other was of Sicilian origin. ${ }^{5}$ This raises the possibility that there may be other genetic loci in different ethnic groups. We have examined a family of Caribbean origin, to determine whether or not there is linkage to the $3^{\prime} H V R$ probe. The disease in this family has led to renal failure between 33 and 44 years of age and in II. 7 and II $\cdot 9$ (fig 1 ) first presented with proteinuria and hypertension in pregnancy.

S W Thames Regional Genetics Service, St George's Hospital Medical School, Cranmer Terrace, London SW17 ORE.

S Jeffery, M Patton

St Thomas's Hospital, Lambeth Palace Road, London SE1.

A J Wing

Correspondence to Dr Jeffery.

Received for publication 4 April 1990

Revised version accepted for publication 29 October 1990

\section{Methods}

The probes used in the study are 24-1 (D16S80) from Dr Breuning of Leiden, and 3'HVR (D16S85) from Dr Higgs at the John Radcliffe Hospital, Oxford. These probes were labelled with ${ }^{32} \mathrm{dCTP}$ using a random hexanucleotide labelling kit from Amersham. DNA was extracted from whole blood using the method of Kunkel $\mathrm{et}_{\mathrm{al}}{ }^{7}$ and digested with PvuII and TaqI for use with $3^{\prime} \mathrm{HVR}$ and 24-1 respectively, in accordance with the manufacturer's (Anglian) instructions. DNA samples were electrophoresed on either $0.9 \%$ or $1.5 \%$ agarose gels and blotted onto Hybond-N membranes (Amersham) by the method of Southern. ${ }^{8}$ Two and three point linkage analyses were carried out using the LINKAGE programme.'

\section{Results and discussion}

The pedigree of the family is shown in fig 1 . The 24-1 probe is not informative for this family, as the affected mother $(\mathrm{I} \cdot 5)$ is homozygous B1B1. ${ }^{10}$ Of the seven members of the pedigree with APKD, six gave blood samples for DNA analysis. The mother $(I \cdot 5)$ was apparently homozygous when the samples were run on $0.9 \%$ agarose gels. However, good separation of two different alleles was achieved on a $1.5 \%$ agarose gel (fig 2, lane 6). All affected members who gave blood carried the $2 \cdot 2 \mathrm{~kb} 3^{\prime} \mathrm{HVR}$ allele from the mother (lanes, 1, 2, 7, 8, 9, fig 2), while the one unaffected daughter who gave DNA had inherited the other allele (lane 3, fig 2). There is one recombination event between $24-1$ and $3^{\prime}$ HVR in subject III 6 , or III $\cdot 8$, since the phase of $24-1$ and $3^{\prime} H V R$ alleles in one of these subjects is different from that in the father.

A two point analysis was carried out for $3^{\prime} H V R$ and PKD1 (so designated to distinguish it from the PKD2 locus unlinked to chromosome 16), using the M-LINK programme of LINKAGE. A lod score of 1.48 was generated at a recombination frequency of 0.06 . This gives a likelihood of 30:1 in favour of the disease being linked to $3^{\prime} \mathrm{HVR}$. Clearly the number of meioses in this pedigree are not sufficient to generate a more significant lod score, but the prior probability 


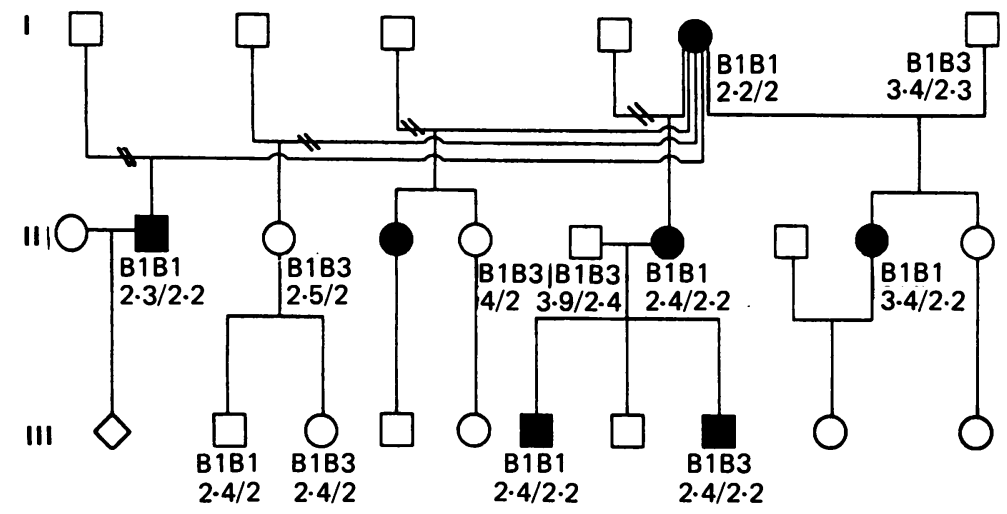

Figure 1 Family pedigree. BI and $B 3$ are alleles of probe $24-1 .^{8}$ Alleles of $3^{\prime} H V R$ are numbered (in $k b$ ).

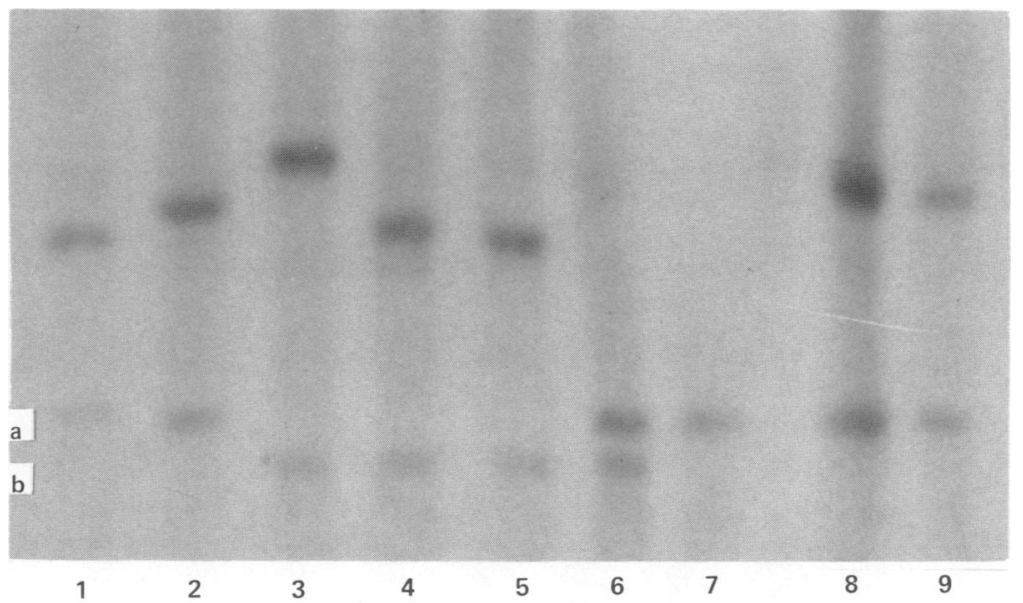

Figure 2 Autoradiograph obtained after hybridisation with the $3^{\prime} H V R$ probe. The DNA had been digested with PvuII and electrophoresed in a $1 \cdot 5 \%$ agarose gel. A total of $5 \mu \mathrm{g}$ of DNA was loaded in each lane. Markers were run on the gel and photographed to obtain estimates of band sizes. Subjects shown on the gel are: lane (I) II $\cdot 7^{*},(2) I I I \cdot 8^{*},(3)$ $I I \cdot 3,(4) I I I \cdot 3$, (5) $I I I \cdot 2,(6) I \cdot 5^{*}$, (7) $I I \cdot 9^{*},(8) I I \cdot 2^{*},(9) I I I \cdot 6^{*}$. (a) is the $2 \cdot 2 \mathrm{~kb}$ allele, $(b)$ is the $2 \mathrm{~kb}$ allele. ${ }^{*}$ Indicates clinically affected.

of linkage suggested by previous studies makes it highly likely that the disease in this family tracks with the PKD1 locus on chromosome 16. A further three point analysis test for heterogeneity using M-LINK gave a lod of 1.59 in favour of the order $3^{\prime}$ HVR$P K D-24-1$, as opposed to $P K D-3{ }^{\prime} \mathrm{HVR}-24-1$, where the recombination distances were $0.06,0.05$, and 0.5 , $0 \cdot 11$ respectively. Again, the likelihood against the disease locus lying outside the two markers is in the order of 30:1. Whether this family is typical of other Caribbean pedigrees remains to be seen, but it does suggest that the most common locus for APKD in other ethnic groups will again be on chromosome 16. As for the position of the locus for PKD2, it is of interest that a recent report has shown a lod score of $>2.0$ for the polymorphic marker YNH24 on chromosome $2 p$ in the case of a large Danish pedigree. ${ }^{11}$
We would like to thank Dr Higgs for probe 3'HVR, Dr Breuning for probe 24-1, and Mrs V Howick for collecting blood samples. We are also grateful to EEC Concerted Action on APKD, organised by $\mathrm{Dr}$ Breuning, for assisting in our research into families with APKD.

1 Reeders ST, Breuning MH, Davies KE, et al. A highly polymorphic DNA marker linked to adult polycystic kidney disease on chromosome 16. Nature 1985;317:542-4.

2 Reeders ST, Breuning MH, Ryynanen MA, et al. A study of genetic linkage heterogeneity in adult polycystic kidney disease. Hum Genet 1987;76:348-51.

3 Lazarou LP, Davies F, Sarfarazi M, Coles GA, Harper PS. Adult polycystic kidney disease and linked RFLPs at the $\alpha$ globin locus: a genetic study in the South Wales population. $\mathcal{F}$ Med Genet 1987;24:466-73.

4 Romeo G, Devoto M, Costa G, et al. A second genetic locus for autosomal dominant polycystic kidney disease. Lancet 1988 ;ii: 7-10. 
5 Kimberling WJ, Fash PR, Kenyon JB, et al. Linkage heterogeneity of autosomal dominant polycystic disease. N Engl $\mathscr{f}$ Med 1988;319:913-8.

6 Nørby S, Sørensen AWS, Boesen P. Non-allelic genetic heterogeneity of autosomal dominant polycystic kidney disease? In Bartsocas C, ed. Genetics of kidney disorders. Proceedings of 5th international clinical genetics seminar. Vol 1. New York: Alan R Liss, 1989:83-8.

7 Kunkel LM, Smith KD, Boyer SH, et al. Analysis of human Y-chromosome specific reiterated DNA in chromosome variants. Proc Natl Acad Sci USA 1977;74:1245-9.
8 Southern $M$. Deletion of specific sequences among DNA fragments separated by gel electrophoresis. F Mol Biol 1975;98: 503-17.

9 Lathrop GM, Lalouel JM. Easy calculations of lod scores and genetic risks on small computers. Am $\mathcal{F}$ Med Genet 1984;18: $45-53$.

10 Breuning MH, Brunner $\mathrm{H}$, Saris JJ, et al. Improved early diagnosis of adult polycystic kidney disease with flanking DNA markers. Lancet 1987;ii:1359-61.

11 Nørby S, Schwartz M. Possible locus for polycystic kidney disease on chromosome 2. Lancet 1990;336:323. 